This item was submitted to Loughborough's Research Repository by the author.

Items in Figshare are protected by copyright, with all rights reserved, unless otherwise indicated.

\title{
Managing change in BIM-Level 2 projects: benefits, challenges, and opportunities
}

PLEASE CITE THE PUBLISHED VERSION

https://doi.org/10.1108/BEPAM-09-2018-0114

\section{PUBLISHER}

Emerald

VERSION

AM (Accepted Manuscript)

\section{PUBLISHER STATEMENT}

This paper was accepted for publication in the journal Built Environment Project and Asset Management and the definitive published version is available at https://doi.org/10.1108/BEPAM-09-2018-0114

\section{LICENCE}

CC BY-NC-ND 4.0

\section{REPOSITORY RECORD}

Blay, Karen, Martin Morgan Tuuli, and Jojo France-Mensah. 2019. "Managing Change in Bim-level 2 Projects: Benefits, Challenges, and Opportunities". figshare. https://hdl.handle.net/2134/37947. 


\section{Managing change in BIM-Level 2 projects: benefits, challenges, and opportunities.}

Karen Blay. ${ }^{1}$, Martin Tuuli ${ }^{2}$ and Jojo France-Mensah ${ }^{3}$

${ }^{1}$ School of Architecture, Building and Civil Engineering Loughborough University, Loughborough, LE11 $3 T U$

2Ghana Institute of Management and Public Administration, Greenhill, P. O. Box AH50, Achimota, Accra-Ghana

${ }^{3}$ Department of Civil, Architectural, and Environmental Engineering the University of Texas at Austin, Austin, TX 78712-1094

\section{Abstract}

\section{Purpose}

The aim of this paper is to validate perceived benefits and challenges of BIM-Level 2 in managing change in projects and identify opportunities for enhancing these benefits and reducing the challenges. This research is timely because, these benefits and challenges remain largely unvalidated following the passing of the BIM-Level 2 mandate in the UK, and the opportunities for enhancing the benefits and reducing challenges remain relatively unexplored.

\section{Design/methodology/approach}

To achieve the aim, questionnaires were sent to BIM-Level 2 practitioners in the UK; in all, 41 responses were received. Following that, interviews with 10 BIM practitioners were carried out to identify opportunities for reducing challenges and increasing benefits.

\section{Findings}

From the findings, the benefits from the literature were all validated. Beyond these, some emergent benefits were identified, such as cost saving and risk reduction. Most challenges from the literature were validated with emergent challenges identified, largely to do with the social dimension in the BIM-Level 2 process. Opportunities identified to enhance benefits and reduce challenges were mainly socially driven. These opportunities were classified as either reactive or proactive.

\section{$\underline{\text { Research limitations/implications }}$}

Opportunities for reducing challenges and increasing benefits identified from this research can inform the change management processes in BIM-Level 2.

\section{Practical implications}

Findings show the processes and requirements for managing change in BIM-level 2

\section{$\underline{\text { Social implications }}$}

The identification of behaviours reveals the social requirements for BIM-level 2.

\footnotetext{
${ }^{1}$ K.b.blay@lboro.ac.uk
} 


\section{Originality/value}

This research identifies opportunities required to reconstruct the change management process in BIMLevel 2. This forms a basis for future work to explore the antecedents of these social requirements.

Keywords: BIM-Level 2-enabled project, change management, benefits, challenges, opportunities

\subsection{Introduction}

Projects exist in a drifting environment and this causes continual deviation from planned works, also known as change (Motawa et al., 2007; Chen et al., 2015). Change is the only certainty in projects and its management is key to the success of infrastructure project management (Zeb et al., 2015). Change is managed by the continual renewal of the direction and structure of projects (Chen et al., 2015). Approaches in the Architecture, Engineering, and Construction (AEC) sector to manage change are developed from constructivism theories, where new processes and procedures based on experience are constructed as the norm (Glaser, 2002). Dimensions of the constructivism theories for change management are the reactive and proactive processes, where the reactive processes are those employed following a change to remedy its impact, and proactive processes are those pre-prepared to minimize disruptive effects of the changes (Motawa et al., 2007). Digitisation in projects, has to date influenced the reactive and proactive processes due to the socio-technical drivers required; a change from the socioapproach.

Specifically, within the AEC sector, Building Information modelling (BIM), which can be described as a socio-technical process; combining man-made technology and social behaviours, to enable collaboration throughout the project lifecycle (Building Smart, 2016) has revolutionised change management in projects. The adoption of BIM in the United Kingdom (UK) across the design, construction and operation of built assets has increased from 48\% in 2015 to $62 \%$ in 2017 (NBS, 2017). To date, BIM-Level 2 is the highest compulsory level being achieved on government projects in the UK following the passing of the BIM mandate in April 2016 and it is characterised by a collaborative working environment and requires coordinated information exchange between systems and parties in the project. The BIM-Level 2 mandate was driven by the UK government's 2011 Construction Strategy to ensure collaboration, efficiency, innovation and value across all areas in the industry (NBS, 2017). Earlier BIM-Levels, that is, Levels 0 and 1 are both non-collaborative and employed for Production Information stages, whilst the future BIMLevel 3, is to achieve international 'Open Data' standards (NBS, 2017).

The collaborative platform in BIM-Level 2 has revolutionised the processes of change identification, analysis, monitoring and control. Prior to the BIM era, that is, in non-BIM enabled projects, change was managed in three ways; by the project phase (example Hao et al., 2008a), by a generic template (example Hayes, 2014) or by a dynamic template approach (example Lee and Peña-Mora, 2007). The project phase approach focuses on promoting a balanced change culture, recognising change, evaluating change, implementing change, and continually improving knowledge sharing following a change event across the project lifecycle (that is, specification, design and construction) (Construction Industry Institute,1994). This approach of managing change is criticised for its lack of collaboration and preparedness towards uncertain change events. Earlier studies proposed a template approach aimed at managing change through a set of sequential steps. The steps comprised; start up, identify and evaluate, approval and propagation and post stage (example; Hayes 2014: Motawa et al., 2007). Change managed using this approach is also criticised for lack of collaboration and its lack of specificity in managing 
change. The dynamic template approach, on the other hand, minimises the impact of change by capturing feedback processes caused by the change and thus, makes the generic processes more effective (Lee and Peña-Mora, 2007). It works by focusing on the control aspect at operation and planning stages and allowing variables to be updated through simulation. The success of this approach is based on the workflow and the use of non-object-oriented information. These are however criticised for the human errors in identification of change and the need to employ technological tools because of their compliance, real-time traceability and collaboration (Karimidorabati, Haas and Gray, 2016; Liyanage, 2016). The dynamic template approach is also criticised for its lack of collaboration (Whyte et al., 2016).

To date, several studies (example Arayici et al. 2011; Azhar, 2011) have identified benefits and challenges in managing change on BIM-Level 2 projects. This notwithstanding, these studies were carried out during the early adoption of BIM processes but prior to the passing of the BIM mandate and emergent collaborative technologies. Hence, the findings of these studies may not accurately reflect the reality (in terms of applications, benefits, and challenges) in the AEC industry today. As such, the aim of this research is to validate the perceived benefits and challenges for managing change in BIM-Level 2 and identify opportunities to enhance these benefits and reduce challenges to inform future constructivism processes and procedures in managing change. The anticipated findings can open more up-to-date dialogue on current BIM adoption practices and highlight new areas of research towards enhancing BIM policies. Therefore, the study seeks to answer two major questions, 'which of the earlier identified benefits and challenges of BIM are experienced in managing change in current BIM-Level 2 projects?' and 'how can these benefits and challenges be improved and reduced respectively?'. These questions are addressed through a systematic process of data collection, analyses and, challenging the emergent findings with current debates in the literature.

The rest of the paper is organised into sections as follows; 2) managing change in BIM-enabled projects - identifies and discusses benefits and challenges in BIM-Level 2 through a thorough review of literature; 3) Methodology - which describes how the identified benefits and challenges are validated through questionnaire survey and opportunities for enhancing benefits and reducing challenges are identified through interviewing practitioners; 4) Results and analysis - presents and explains the findings from the questionnaire survey and interviews; 5) Discussion - relates key findings to literature and 6) Conclusions - outlines key conclusions and their implications.

\subsection{Managing change in BIM-enabled projects}

The change management process in a BIM-enabled project comprises an existing plan, change identification, change resolution, knowledge sharing and close change. These stages were deduced by employing the theory of conceptual clustering (Stepp \& Michalski, 1986) as a lens. Within this, the change management stages within literature were abstracted and grouped based on the conceptual descriptions of each category to identify the stages, similitudes and any areas of discrepancies. Within the stages, change is managed through automation and iterative processes in the Common Data Environment (CDE) workflow. $\mathrm{CDE}$ is the online platform for collecting, managing and sharing information (Alreshidi et al. 2017). The benefit of automated updates, contrary to non-BIM change management approaches (Peterson et al., 2011), is that, it provides a common understanding of the change process, eliminates change redelivery (Karimidorabati, Haas and Gray, 2016) and avoids common problems in non-BIM projects such as loss of information and delay in communication (Erdogan et al., 2005). BIM-Level 2 provides less Request for Information (RFl's) and change orders and enhances clarity (Sanchez et al., 2016). 
The Existing plan stage in BIM-Level 2-enabled projects allows leveraging contingencies to manage change. BIM-Level 2 projects use virtual and in-person discussions, meetings and the promotion of quality assurance (Chen and Luo, 2014) for effective communication and collaboration ahead of change identification. Change identification occurs at different stages within the project. In BIM-Level 2-enabled projects, change identification occurs early-on because of the CDE which promotes integration and the early detection of clashes (Azhar, 2011; Hardin and McCool, 2015). Based on the promotion of early collaboration in the BIM-Level 2-enabled projects, all parties in the project are involved from the beginning of the project through to the end with new members automatically updated once enrolled onto the CDE.

Change resolution in a BIM-Level 2-enabled project is through contingency allowance and altering the existing plan based on the contractual agreement (Abd Jamil and Fathi, 2018). Change resolution is quicker in BIM-enabled projects because it enables the parties to visualise different perspectives and thus, assess different perspectives, to promote lateral thinking (Liu et al., 2014; Eadie, Browne and Odeyinka, 2015). BIM-Level 2-enabled projects drive knowledge sharing through collaborative platforms and update existing plans with new information. They promote the sharing of experiences and clarifications of past experiences to be incorporated in a change plan. In addition to the CDE, virtual presentations and workshops ensure that all parties have a common understanding. Following knowledge sharing, change is archived in the virtual collaborative platform and used in cases where disputes arise.

\subsection{Benefits of managing change in a BIM-enabled projects}

The benefits of managing change in BIM-Level 2-enabled projects as synthesised from the literature comprising journals and documented case studies are outlined in Table 1. The benefits were deduced by carrying out critical literature reviews of papers on the collaborative process within a BIM-enabled projects. Several searches were carried out by keying in words such as Building Information Modelling (BIM), collaboration + projects, change management + BIM Level-2 (with the focus on UK). At the end of the search, 45 papers were identified in Scopus, 26 in Engineering Village and 196 on Google Scholar. Amongst these, papers published in high-ranked journals using the Source Normalized Impact per Paper (SNIP) and impact factors as the justification criteria were reviewed. SNIP measures the average citation impact of a journal between scientific fields. The other 21 papers were also read to ensure that no important data was ignored. BIM databases in the UK were also reviewed to identify documented case studies.

Within Table 1, the frequency count, is deduced from rigorous, objective analysis of the data from the papers and case studies and shows the number of specific benefits that were evident. Each count, ' $V$ ', depicts the evidence of the benefits in a paper. This frequency count follows the Credential Counting theory which enables the generation of transparent quantifiable evidence from external sources (Hannah and Lautsch, 2011). BIM-Level 2 enabled case studies documented in Government approved databases were also reviewed to capture the evidence of benefits. The identified benefits were coded under emerging themes using Nvivo 10 and captured in Table 1.

Challenges in non-BIM-enabled projects such as the inability to manage change adequately due to lack of collaboration, compartmentalisation of the change management process, lack of specificity and human errors in identifying and rectifying changes have been largely resolved within BIM-Level 2-enabled 
projects (Karimidorabati, Haas and Gray, 2016; Hardin and McCool, 2015). These are achieved by the continual communication in person and virtually amongst parties from design through to the construction stages, the use of clash reports and sharing of documents in the CDEs to enhance visual identification of specific changes and clarity required.

Table 1: Benefits of managing change in BIM-Level 2 enabled projects

\begin{tabular}{|c|c|c|c|c|c|c|c|}
\hline \multirow[b]{2}{*}{ Author/Case study } & \multirow[b]{2}{*}{$\begin{array}{l}\text { Less } \\
\text { RFI }\end{array}$} & \multirow[b]{2}{*}{$\begin{array}{l}\text { Less } \\
\text { change } \\
\text { orders }\end{array}$} & \multirow[b]{2}{*}{$\begin{array}{l}\text { Early } \\
\text { collaboration }\end{array}$} & \multicolumn{2}{|c|}{ Benefits } & \multirow[b]{2}{*}{$\begin{array}{l}\text { Less duration for } \\
\text { change } \\
\text { implementation }\end{array}$} & \multirow[b]{2}{*}{$\begin{array}{l}\text { Quality } \\
\text { Assurance }\end{array}$} \\
\hline & & & & $\begin{array}{l}\text { Visual } \\
\text { confirmation } \\
\text { through clashes } \\
\text { and redlining }\end{array}$ & $\begin{array}{l}\text { Clarity in } \\
\text { communication }\end{array}$ & & \\
\hline $\begin{array}{l}\text { Barlish \& Sullivan } \\
\text { (2012) }\end{array}$ & V & V & V & $\mathrm{V}$ & & V & $\mathrm{V}$ \\
\hline Azhar (2011) & & & V & V & V & & \\
\hline $\begin{array}{l}\text { Hardin and McCool } \\
\text { (2015) }\end{array}$ & V & V & V & V & V & & \\
\hline Bryde at al (2012) & V & V & V & & V & & $\mathrm{V}$ \\
\hline $\begin{array}{l}\text { Ghaffarianhoseini et al } \\
\text { (2017) }\end{array}$ & V & V & V & V & & V & V \\
\hline $\begin{array}{l}\text { Newton \& Chileshe } \\
\text { (2012) }\end{array}$ & & & V & V & & V & \\
\hline Farnsworth et al. (2015) & & V & & V & V & & \\
\hline $\begin{array}{l}\text { Doumbouya, Goa and } \\
\text { Guan (2016) }\end{array}$ & V & V & V & V & V & V & \\
\hline Talebi (2014) & V & V & V & V & V & V & \\
\hline Chen and Luo (2014) & & V & V & V & V & & $\mathrm{V}$ \\
\hline Lui et al (2014) & V & $\mathrm{V}$ & & & & V & $\mathrm{v}$ \\
\hline $\begin{array}{l}\text { Karimidorabati, Haas } \\
\text { and Gray (2016) }\end{array}$ & V & V & & V & & & \\
\hline Peterson et al. (2011) & & V & & & & V & \\
\hline $\begin{array}{l}\text { Caballero (2017)-Case } \\
\text { study } 1\end{array}$ & V & V & V & V & V & & \\
\hline $\begin{array}{l}\text { BIMPlus (2017)- Case } \\
\text { study } 2\end{array}$ & V & & V & V & & V & V \\
\hline $\begin{array}{l}\text { Skanska (2018) Case } \\
\text { study } 3\end{array}$ & V & V & V & V & V & V & V \\
\hline $\begin{array}{l}\text { BIMPlus (2017)- Case } \\
\text { study } 4\end{array}$ & V & V & V & V & V & V & \\
\hline $\begin{array}{l}\text { BIMPlus (2017)- Case } \\
\text { study } 5\end{array}$ & & V & V & V & V & V & V \\
\hline $\begin{array}{l}\text { BIMPlus (2017)- Case } \\
\text { study } 6\end{array}$ & V & V & V & V & V & & \\
\hline Frequency & 13 & 16 & 15 & 16 & 12 & 11 & 8 \\
\hline
\end{tabular}

BIM-Level 2 reduces RFl's by 32\% (PwC, 2018) and provides efficiency from the beginning of the project through early collaboration (Talebi, 2014). Early collaboration in BIM-Level 2 projects also reduces cost due to claims and discrepancy avoidance it provides (Talebi, 2014). The integrated project delivery in BIM-Level 2 projects provides visual confirmation of automated changes through clashes and redlining and thus, clarity in communication (Ghaffarianhoseini et al., 2017). The BIM-process, therefore, leads to less duration for change implementation and ensures Quality Assurance through a virtual representation of the actual work. These benefits of BIM-Level 2 have modified the change management process and thus, practitioner behaviours towards a more collaborative working culture.

\subsection{Challenges of managing change in BIM-Level 2-enabled projects}

Change management in BIM-Level 2-enabled projects has many challenges as captured in Table 2. From the challenges, the lack of interoperability between parties is influenced by the inability to pay for the cost of acquiring the same software for all parties. This is evidenced by subcontractors acquiring software within their budget which may not necessarily be interoperable with systems being used by other members of the project team. Despite efforts to include the software requirement in the Employers 
information requirements (EIR), practitioners prefer to adopt Industry Foundation Classes (IFC) which is cheaper and in turn limits automation of changes (Azhar, Khalfan and Maqsood, 2015). Other challenges such as lack of BIM skills is recommended to be resolved by BIM-training in organisations and projects and the expansion of the BIM manager role to train staff however, these are challenged by lack of resources (Tulubas and Arditi, 2017; Elmualim and Gilder, 2014). Moreover, the lack of clarity of the COBie datasets is also due to the inconsistency in the naming conventions. The identified challenges bring about other subsequent challenges, therefore, identifying opportunities to minimize these challenges will go a long way to employ BIM-Level 2 efficiently.

Table 2: Challenges in managing change in BIM-enabled projects

\begin{tabular}{|c|c|c|c|c|c|c|c|c|}
\hline \multirow[b]{2}{*}{$\begin{array}{l}\text { Author/Case } \\
\text { study }\end{array}$} & \multicolumn{8}{|c|}{ Challenges } \\
\hline & $\begin{array}{c}\text { Lack } \\
\text { of } \\
\text { BIM } \\
\text { skills }\end{array}$ & Interoperability & $\begin{array}{l}\text { Unavailable } \\
\text { information }\end{array}$ & $\begin{array}{l}\text { Organisational } \\
\text { cultural } \\
\text { differences }\end{array}$ & $\begin{array}{c}\text { Access } \\
\text { restriction to } \\
\text { all } \\
\text { information }\end{array}$ & $\begin{array}{l}\text { Lack of clear } \\
\text { Responsibility } \\
\text { allocation }\end{array}$ & $\begin{array}{l}\text { More time } \\
\text { spent in } \\
\text { explaining } \\
\text { COBie }\end{array}$ & $\begin{array}{l}\text { Inconsistency } \\
\text { in file naming }\end{array}$ \\
\hline $\begin{array}{l}\text { Anderson et al } \\
\text { (2012) }\end{array}$ & $\mathrm{V}$ & & & & & & $\mathrm{V}$ & \\
\hline $\begin{array}{l}\text { Azhar et al } \\
(2015)\end{array}$ & V & V & v & & & V & & v \\
\hline $\begin{array}{l}\text { Hardin and } \\
\text { McCool (2015) }\end{array}$ & V & v & & & V & V & & v \\
\hline $\begin{array}{l}\text { Arayici at al } \\
\text { (2011) }\end{array}$ & V & & & V & & & & V \\
\hline $\begin{array}{l}\text { Elmualim and } \\
\text { Gilder (2014) }\end{array}$ & V & V & & & & V & & \\
\hline $\begin{array}{l}\text { Khosrowshahi } \\
\text { and Arayici } \\
\text { (2012) }\end{array}$ & V & V & & V & V & & & \\
\hline $\begin{array}{l}\text { Gledson and } \\
\text { Greenwood } \\
\text { (2016) }\end{array}$ & V & v & & & v & & & \\
\hline $\begin{array}{l}\text { Tulenheimo } \\
\text { (2015) }\end{array}$ & V & V & v & & & & & \\
\hline $\begin{array}{l}\text { Bataw, Burrows } \\
\text { and Kirkhman } \\
\text { (2014) }\end{array}$ & V & v & & V & V & & & \\
\hline $\begin{array}{l}\text { Azhar, Khalfan \& } \\
\text { Maqsood (2015). }\end{array}$ & V & V & & & & V & v & \\
\hline $\begin{array}{l}\text { Caballero } \\
\text { (2017)-Case } \\
\text { study } 1\end{array}$ & V & V & & V & & & v & v \\
\hline $\begin{array}{l}\text { BIMPlus (2017)- } \\
\text { Case study } 2\end{array}$ & & & v & & v & V & v & \\
\hline $\begin{array}{l}\text { Skanska (2018) } \\
\text { Case study } 3\end{array}$ & V & V & v & & & & & V \\
\hline $\begin{array}{l}\text { BIMPlus (2017)- } \\
\text { Case study } 4\end{array}$ & V & & v & V & & V & v & v \\
\hline $\begin{array}{l}\text { BIMPlus (2017)- } \\
\text { Case study } 5\end{array}$ & V & & v & & v & V & & v \\
\hline $\begin{array}{l}\text { BIMPlus (2017)- } \\
\text { Case study } 6\end{array}$ & V & V & & & v & V & v & V \\
\hline Frequency & 15 & 11 & 6 & 5 & 7 & 8 & 6 & 8 \\
\hline
\end{tabular}




\subsection{Methodology}

Benefits and challenges in Tables 1 and 2 require validation to establish the extent to which they generalise in practice since the passing of the BIM mandate in the UK. A questionnaire survey was identified as the most appropriate approach for undertaking the validation due to the large number of respondents that can be reached to enable the establishment of extent that the benefits generalise. 120 questionnaires were sent out to practitioners in the UK working on BIM-Level 2 enabled government projects using the Bristol Online Survey (BOS) platform. The questions required practitioners to indicate which of the benefits and challenges identified from the literature were deemed valid from their experience and to further identify any new benefits or challenges based on their experience. The questions were sent to Architects, Quantity Surveyors, Civil Engineers, BIM Managers, Project managers, Mechanical and Electrical engineers and Design managers who are or have worked on BIM-Level 2 enabled projects. The criteria for selecting these respondents include; 1) having experience in working in a BIM-Level 2 project, 2) worked on at least one government project, 3) worked for at least 2 years in the construction industry and on BIM-Level 2 project. These criteria were employed to ensure that appropriate respondents were selected, and the respondents answered the questionnaire based on actual experience working on BIM-Level 2 projects.

Opportunities for enhancing benefits and reducing challenges also needed to be identified and the interview approach was deemed the most appropriate approach to adopt. Interviews enable practitioners to reveal and describe (Fellows \& Liu, 2008) opportunities for enhancing benefits and reducing challenges. As such, semi-structured interviews, which consist of questions to define an area of exploration and enables the interviewer to ask direct questions of specific areas of interest (Green et al., 2010) was the most appropriate option. Following the questionnaire survey, respondents were asked if they would volunteer to be interviewed and 10 interviews were granted to identify opportunities for enhancing benefits and reducing challenges. The selected practitioners were located across England (north and south) and included personnel of varied experiences in the construction industry. The practitioners had worked for an average of 15 years in construction and worked on at least 2 BIM-Level 2-enabled projects. Questions asked comprised project details, perceived benefits and challenges, and opportunities for enhancing benefits and reducing challenges. Figure 1 captures an overview of the methodology employed in this study.

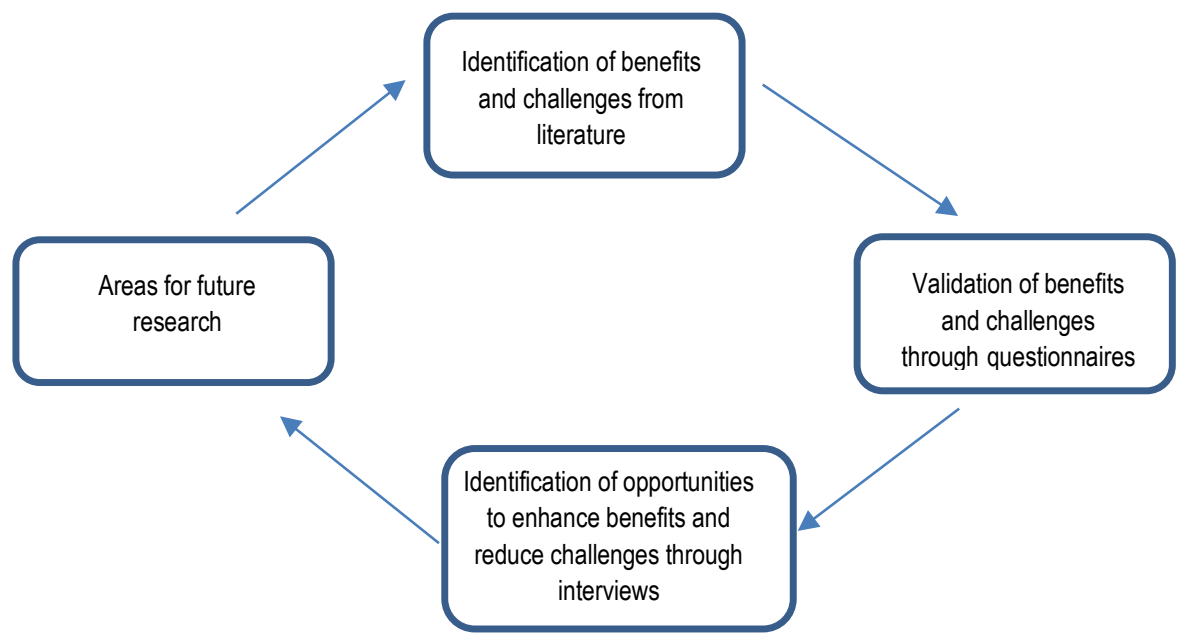

Figure 1: Methodological overview 


\subsection{Results and Analysis}

\section{Questionnaire Survey}

From the questionnaire survey, 41 responses were received out of which 23 were BIM managers, 8 Architects, 3 Project managers, 2 Design managers and 5 were BIM consultants. The number of responses translates to a $34 \%$ response rate which is adequate for a study of this scale in the construction industry (Newton \& Chileshe, 2012) given the limited professionals with BIM-Level 2 experience. Respondents had an average of 15 years work experience in their respective roles except for the BIM managers and BIM consultants who had worked a maximum of 2 years. The 2-year experience could be attributed to the relatively new nature of these roles which emerged as a result of the government mandate to employ BIM-Level 2 in recent times (thus, 2016 to 2018). 70\% of respondents had worked on more than 3 BIM-Level 2 enabled projects depicting the survey respondents in-depth experience of BIM-Level 2 projects.

Respondents were required to rate responses on a scale of 1 to 4 , where 4 is a very important benefit, 3 is an important benefit, 2 is not an important benefit, and 1 is not a benefit. Benefits from the literature were confirmed by the majority (86\%) (thus, scoring 2 and above) of respondents whilst a few respondents thought otherwise. Specifically, $14 \%$ of respondents thought 'Less duration for change' and 'Visual confirmation' were not benefits. Figure 2 below captures the benefits that were confirmed by respondents.

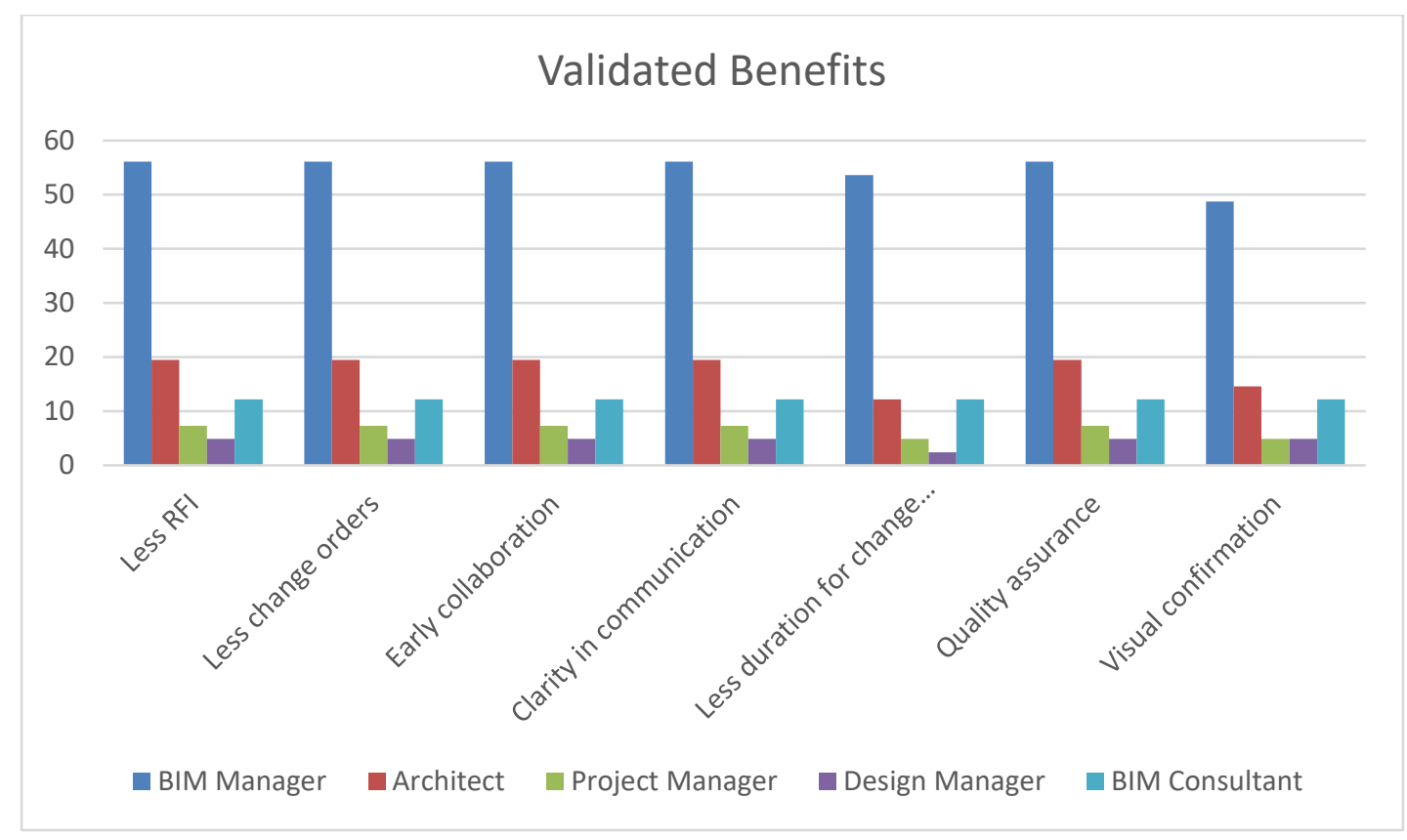

Figure 2: Validated benefits of employing BIM-Level 2 in managing change

In addition to confirming benefits from literature, other benefits such as cost savings and risk reduction with offsite construction were identified by $68 \%$ and $40 \%$ of respondents respectively.

Challenges such as lack of BIM skills, interoperability, unavailable information, organisational culture differences, access restriction to information, lack of clear responsibility and more time spent in explaining COBie were confirmed by over $80 \%$ of respondents (scoring 2 and above) to be a challenge. Emergent challenges identified include 'Inconsistent object naming and classification, lack of LEAN/BIM integration'; 
'Lack of understanding commercial aspects, not understanding the implications of what is being agreed'; and 'Client Requirements for BIM not being sufficiently prescriptive', were identified by $40 \%, 28 \%, 12 \%$ and $20 \%$ of respondents respectively. The results showed substantial agreement amongst respondents with a Kappa value of 0.61 (Landis and Koch, 1977).

\section{Interviews}

Following the responses from the questionnaire, interviews with 4 project managers and 6 BIM managers were carried out to identify opportunities for enhancing the validated benefits and reducing the identified challenges. The interviews lasted for an average of 45 minutes per person and the questions comprised their demographic information (example job role, gender, years of experience, number of BIM-Level 2 projects worked on and professional affiliation (as shown in Table 3)) and their perceptions on opportunities for enhancing the validated benefits (Early collaboration, Visual confirmation, Clarity in communication, Less duration for change implementation, Less change orders, Less RFI and Quality Assurance) and reducing the identified challenges (Extra time required to explain BIM process to parties, Inconsistency in object naming conventions, Lack of skills, Interoperability, Unavailable information, Organisational cultural differences, Access restriction to all information, Lack of clear and Responsibility allocation).

Results of the interviews are reported under two broad themes; metadata of respondents, and opportunities for enhancing the validated benefits and reducing the identified challenges. The metadata of respondents is summarised in Table 3. As shown in the table, all the interviewees are adequately qualified to provide opinions on how to enhance benefits and reduce impact of challenges based on their respective experience in the industry and on BIM-Level 2 projects specifically.

Table 3: Metadata of respondents

\begin{tabular}{|c|c|c|c|c|c|}
\hline Location & $\begin{array}{l}\text { Project/BIM } \\
\text { manager } \\
\text { (PM/BM) }\end{array}$ & Gender & $\begin{array}{l}\text { Years of } \\
\text { experience in } \\
\text { construction }\end{array}$ & $\begin{array}{l}\text { Number of BIM- } \\
\text { Level-2 projects } \\
\text { worked on }\end{array}$ & Professional affiliation \\
\hline \multirow{5}{*}{$\begin{array}{l}\text { Northern part } \\
\text { of England }\end{array}$} & PM-01 & Female & 21 & 2 & Association of Project Managers \\
\hline & PM-02 & Male & 15 & 2 & Association of Project Managers \\
\hline & BM-03 & Male & 9 & 4 & Charted Institute of Builders \\
\hline & BM-04 & Male & 12 & 3 & $\begin{array}{l}\text { Architectural Retraction Board } \\
\text { (ARB) }\end{array}$ \\
\hline & BM-05 & Male & 15 & 2 & $\begin{array}{l}\text { Royal Institute of British Architects } \\
\text { (RIBA) }\end{array}$ \\
\hline \multirow{5}{*}{$\begin{array}{l}\text { Southern part } \\
\text { of England }\end{array}$} & PM-06 & Male & 9 & 3 & Association of Project Managers \\
\hline & PM-07 & Male & 8 & 2 & Charted Institute of Builders \\
\hline & BM-08 & Male & 11 & 2 & $\begin{array}{l}\text { Royal Institute of Charted Surveyors } \\
\text { (RICS), Charted Institute of Builders }\end{array}$ \\
\hline & BM-09 & Male & 36 & 2 & Association of Project Managers \\
\hline & BM-10 & Male & 11 & 3 & Association of Project Managers \\
\hline
\end{tabular}


From the interviews, opportunities for enhancing benefits and reducing challenges were identified after iterative coding of the data using Nvivo 10. The data was coded under the two main dimensions of the constructivism theory: reactive and proactive. Opportunities classed under reactive and proactive were driven by operational and dynamic processes respectively. Operational processes are static, and routinebased due to awareness/knowns, whilst dynamic processes are vision oriented due to the lack of knowledge of the immediate future (Engwall, 2002; Davies and Brady, 2016). Tables 4 and 5 summarise evidence of key reactive and proactive measures from the BIM and project managers.

Table 4: Summary of reactive and proactive opportunities for enhancing benefits (from interviewees)

\begin{tabular}{|c|c|c|}
\hline \multirow[b]{2}{*}{ Benefits } & \multicolumn{2}{|c|}{ Opportunities } \\
\hline & Reactive & Proactive \\
\hline $\begin{array}{l}\text { Early } \\
\text { collaboration }\end{array}$ & & $\begin{array}{l}\text { 'Define the client expectation. Using BIM from the start of } \\
\text { the project and not wait till a change event happens } \\
\text { because it slows everything down' (BM-03) }\end{array}$ \\
\hline $\begin{array}{l}\text { Visual } \\
\text { confirmation }\end{array}$ & & $\begin{array}{l}\text { 'A standard way of presenting clash reports should be } \\
\text { provided by all software providers because it looks like } \\
\text { programmes present it differently and this affects us who } \\
\text { move from one project to the other. My issues are with the } \\
\text { inconsistencies with clash labelling, its details and how it is } \\
\text { presented, it slows the change process' (BM-08) }\end{array}$ \\
\hline $\begin{array}{l}\text { Clarity in } \\
\text { communication }\end{array}$ & $\begin{array}{l}\text { 'Ask questions if anything is not clear always } \\
\text { especially when we are trying to effect a change so } \\
\text { that wrong things are not changed instead' (BM-10) }\end{array}$ & $\begin{array}{l}\text { 'Use the same language and communicate always do not } \\
\text { assume anything, seek clarification, there is no stupid } \\
\text { question, we need to ask questions and not assume' (BM- } \\
\text { 04) }\end{array}$ \\
\hline $\begin{array}{l}\text { Less duration for } \\
\text { change } \\
\text { implementation }\end{array}$ & & $\begin{array}{l}\text { 'This is due to automation but what happens is that it takes } \\
\text { the checking factor away from responsible parties, so I will } \\
\text { say people should check and keep checking everything } \\
\text { especially when changes are being managed' (PM-02) } \\
\text { Full collaboration from all parties to ensure transparency } \\
\text { and clarity of expectation from the day the project begins } \\
\text { (BM-09) }\end{array}$ \\
\hline Less RFI & & $\begin{array}{l}\text { Full collaboration from all parties to ensure transparency } \\
\text { and clarity of expectation from the day the project begins } \\
\text { (BM-09) } \\
\text { RFI should be to standard and comply with the Employers } \\
\text { Information Requirements (EIR) (PM-06) }\end{array}$ \\
\hline $\begin{array}{l}\text { Quality } \\
\text { Assurance }\end{array}$ & & $\begin{array}{l}\text { Continual checking of quality through specification and } \\
\text { clash detection should be carried out by all parties and } \\
\text { monitored. Do not leave it for one person (PM-01) }\end{array}$ \\
\hline
\end{tabular}


From Table 4, the reactive opportunity for enhancing the clarity in communication benefit, is to 'ask questions' whilst proactive opportunities for enhancing other benefits include the need for standardised processes and procedures, full collaboration and transparency amongst parties in a Level 2-BIM-enabled project and the need for project parties to check works and not fully rely on the automated processes in determining accuracy.

From Table 5, reactive opportunities such as passing information to the responsible parties, responsibility taking by parties, motivation, and updating files were identified whilst standardisation of process, training and empowering parties, transparency, inclusion, prescriptive requirement and responsibility allocation were the proactive opportunities to reduce challenges.

\section{Table 5: Summary of reactive and proactive opportunities for reducing challenges (from interviewees)}

\begin{tabular}{|c|c|c|}
\hline \multirow[b]{2}{*}{ Challenges } & \multicolumn{2}{|c|}{ Opportunities } \\
\hline & Reactive & Proactive \\
\hline $\begin{array}{l}\text { Extra time required to } \\
\text { explain BIM process to } \\
\text { parties }\end{array}$ & $\begin{array}{l}\text { 'Just do not spend time trying to understand, pass it } \\
\text { on the party best able to or the one who generated } \\
\text { the COBie data' (PM-07) }\end{array}$ & $\begin{array}{l}\text { 'The labelling of CoBie files should be to standard' } \\
\text { (BM-08) }\end{array}$ \\
\hline \multirow[t]{2}{*}{$\begin{array}{l}\text { Inconsistency in object } \\
\text { naming conventions }\end{array}$} & $\begin{array}{l}\text { 'Contact the personnel in charge as soon as this is } \\
\text { noticed and do not keep quiet until issues begin to } \\
\text { emerge, at that time it will be too late. So, it is about } \\
\text { the swift responsibility taking to get things resolved' } \\
\text { (PM-01) }\end{array}$ & $\begin{array}{l}\text { 'All companies on the project should agree on a } \\
\text { same file naming convention' (PM-01) }\end{array}$ \\
\hline & & $\begin{array}{l}\text { 'All files in the project should be labelled to a } \\
\text { standard' (BM-10) }\end{array}$ \\
\hline \multirow[t]{2}{*}{ Lack of skills } & $\begin{array}{l}\text { 'Motivate those with lack of skills to ask questions } \\
\text { each step of the way and then ask the rest of the } \\
\text { team to be willing to teach each other. We know we } \\
\text { are time bound on project, but we will be quicker in } \\
\text { managing change if everyone is on board' (PM-07) }\end{array}$ & $\begin{array}{l}\text { 'Training on the project in organisations should be } \\
\text { promoted and this will save us a lot of time in trying } \\
\text { to explain every step to people' (BM-04) }\end{array}$ \\
\hline & & $\begin{array}{l}\text { 'Clients should check if all employees are BIM- } \\
\text { empowered because it nullifies the solution of } \\
\text { collaboration if majority of people lack the skills } \\
\text { needed' (BM-04) }\end{array}$ \\
\hline Interoperability & $\begin{array}{l}\text { 'Use IFC files but make sure to update drawings once } \\
\text { changes are made' (BM-04) }\end{array}$ & $\begin{array}{l}\text { Software requirements and protocols should be } \\
\text { clearly explained in the EIR, at the beginning of the } \\
\text { collaboration process (PM-01, BM-04) }\end{array}$ \\
\hline $\begin{array}{l}\text { Unavailable } \\
\text { information }\end{array}$ & $\begin{array}{l}\text { 'Contact the personnel in charge as soon as you } \\
\text { realise information is not available. Do not waste time, } \\
\text { every second is money on projects' (BM-10) }\end{array}$ & $\begin{array}{l}\text { We should ensure that all the information required } \\
\text { based on the EIR is available at the beginning of } \\
\text { the project or made ready in time by the } \\
\text { responsible party (BM-08) }\end{array}$ \\
\hline $\begin{array}{l}\text { Organisational cultural } \\
\text { differences }\end{array}$ & & $\begin{array}{l}\text { Team spirit and inclusiveness during the change } \\
\text { issues and this industry needs to avoid blaming } \\
\text { each other as much as possible and take } \\
\text { responsibilities (PM-02, BM03) }\end{array}$ \\
\hline $\begin{array}{l}\text { Access restriction to } \\
\text { all information }\end{array}$ & $\begin{array}{l}\text { 'Contact the personnel in charge as soon as you } \\
\text { realise information is not available. Do not waste time, } \\
\text { every second is money on projects' (BM-10) }\end{array}$ & $\begin{array}{l}\text { The BIM manager should ensure access is given to } \\
\text { the responsible party stated in the BIM execution } \\
\text { plan (BM-03, BM-05) }\end{array}$ \\
\hline $\begin{array}{l}\text { Lack of clear } \\
\text { Responsibility } \\
\text { allocation }\end{array}$ & $\begin{array}{l}\text { 'The party with the highest risk tends to take the } \\
\text { initiative but they should ensure that it does not lead } \\
\text { to a blame game (as it normally does) (BM-10) }\end{array}$ & $\begin{array}{l}\text { 'Client requirements should be fully prescriptive so } \\
\text { that responsibilities can be clearly allocated' (BM- } \\
\text { 09) }\end{array}$ \\
\hline
\end{tabular}




\subsection{Discussion}

\section{Validated benefits and challenges in employing BIM-Level 2}

Validated benefits include visual confirmation, quality assurance, less duration for change implementation, clarity in communication, early collaboration, less change orders and RFI. These confirm benefits outlined in studies prior to the BIM mandate whilst emergent benefits were cost saving and risk reduction with offsite construction. The challenges identified were however different and can be attributed to the modification of the BIM process and collaborative requirements (Lin and Yang, 2018) following the BIM mandate. Challenges such as lack of BIM skills, interoperability, unavailable information, organisational culture differences, access restriction to information, lack of clear responsibility and more time spent in explaining COBie were identified. Emergent challenges such as 'object naming inconsistencies, lack of LEAN/BIM integration'; 'Lack of understanding commercial aspects; and 'Client Requirements for BIM not being sufficiently prescriptive' were also identified. In an earlier study by Chen et al. (2017), the importance of naming conventions to the success of implementation was pointed out. Similarly, some theoretical works on BIM/LEAN integration, such as, Al Hattab and Hamzeh (2015) suggest that, there are still practical aspects of this problem that need to be better explored or addressed. Concerning client requirements, Coates et al. (2010), established that, there is a need to establish a "shared understanding" between parties throughout the BIM adoption process. Thus, it can be observed that there are elements of these challenges that have been explored in the extant literature. These emergent challenges largely capture the social dimensions in the socio-technical process and the lack of in-depth research to address these. It, therefore, creates the need for extensive research on behavioural studies within the digitized process to ensure the effective management of change during the infrastructure projects' drifting environment.

The validated benefits and challenges from this study are timely for infrastructure project management due to the growing digitization in projects (example the Digital Build Britain agenda). In addition, the results identified contribute to debates that seek to examine the 'real-world' implementation of BIM (example Arayici et al. 2011; Azhar, 2011) in managing change in projects and therefore, ensure that the value for employing Level-2- BIM process is achieved.

\section{Opportunities for enhancing benefits and reducing challenges}

Identified opportunities to reduce challenges are largely social-centric and not technology driven as most BIM-enabled research suggest. Specifically, results as captured in Figure 3, point to the need for standardised processes and procedures, full collaboration and transparency amongst parties in a Level 2-BIM-enabled project. This requires behavioural changes such as taking responsibility to check works and not relying on the automated process in determining accuracy. These behavioural-findings add on to existing technological recommendations in a Level 2-BIM-enabled project (example Ghaffarianhoseini et al., 2017) and may influence the development of emerging technologies, tools and techniques employed in projects for managing change and the syntax employed in developing these.

Findings from this study unpacks the collaboration requirements for projects and not the 'parent' organisations of the project actors. This distinction is important because the AEC sector is well collaboratively established at the parent organisation level (example Hughes, William and Ren, 2012) and less collaborative in projects despite employing the BIM process. The focus on change management helps to identify value-added benefits of BIM-Level 2 to motivate non-BIM adopters and highlights areas 
of focus to maximize the economic and social values of adopting BIM-Level-2. This contributes to studies such as Azhar (2011) and the Digital Built Britain agenda to motivate project actors to adopt the BIMLevel 2 process in infrastructure development and planning. These findings can also be employed in the construction industry in other countries where dimensions and antecedents of BIM-Level 2 are evident.

Results show the need for project parties to take responsibility, socially collaborate and work in a collegial environment to promote an inclusive environment as carried out in permanent organisations in addition to the technological collaborative abilities. The behavioural factor of taking responsibility identified, specifically in the need for parties to check outputs, creates opportunities to extend behaviourismtechnology rhetoric in the educational sector (example Akbar, 2013) to the AEC sector. Consideration of the identified opportunities to reduce challenges and enhance benefits within the stages of the change management process in BIM-Level 2 is required and these are synthesized and presented in Figure 3 below. These considerations are to influence the change management process and drive future policies for managing change in BIM-Level 2. 


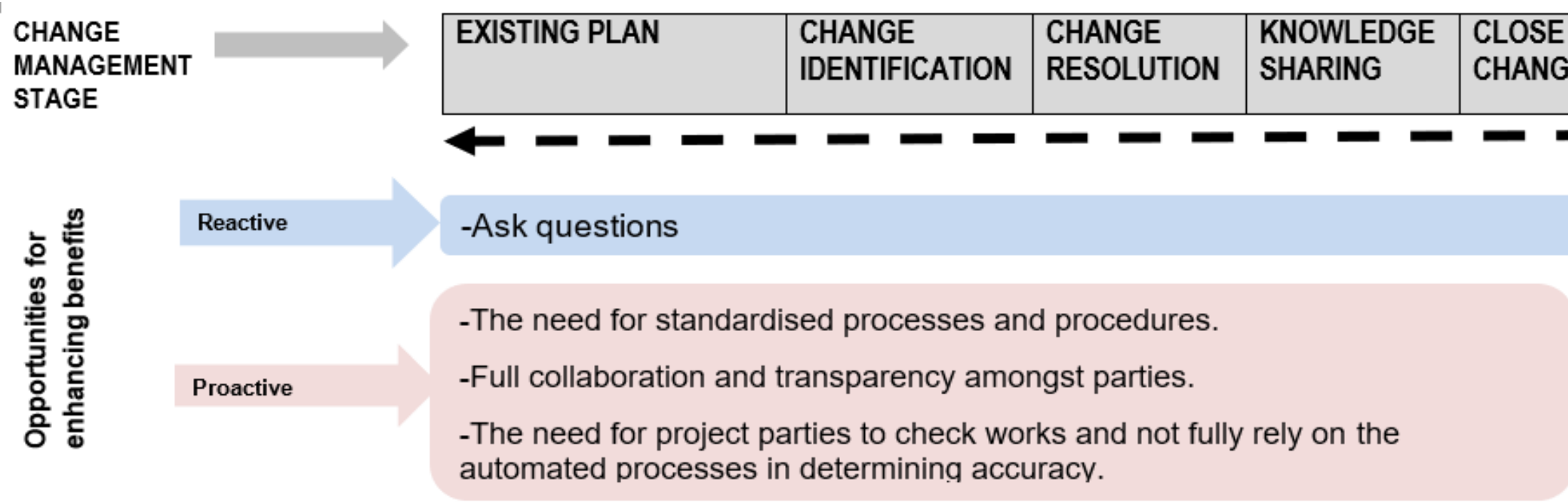

\begin{tabular}{|c|c|c|}
\hline \multirow{4}{*}{ 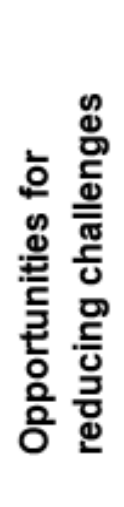 } & \multirow[t]{2}{*}{ Reactive } & $\begin{array}{l}\text {-Passing information to the responsible parties. } \\
\text {-Responsibility taking by parties. } \\
\text {-Motivation. } \\
\text {-Updating files. }\end{array}$ \\
\hline & & $\begin{array}{l}\text {-Standardisation of process and communication. } \\
\text {-Training and empowering parties. }\end{array}$ \\
\hline & Proactive & -Transparency. \\
\hline & & -Prescriptive requirement and responsibility allocation. \\
\hline
\end{tabular}

Figure 3: Relating change management stages in BIM-Level 2 to opportunities for reducing challenges and increasing benefits 


\subsection{Conclusion}

The results in this study validate the benefits and challenges for employing BIM-Level 2 and identifies opportunities to enhance benefits and reduce challenges of employing BIM-Level 2 in the AEC sector. Embedding the opportunities for enhancing benefits and reducing challenges in the change management process in BIM-Level 2-enabled projects will maximize the value of adopting the BIM process. These opportunities represent practical ways or best practices, as suggested by subject matter experts (SMEs) to overcome challenges in change management and inform BIM policies overall. The findings in this study also highlight the social proactive and reactive requirements towards enhancing collaboration in BIMLevel 2 and a guide to emergent BIM adopters when managing change and by adopting them, project participants are more likely to achieve the perceived benefits, while overcoming the challenges through the opportunities. This adds to the seminal sociotechnical recommendations to enhance the BIM process by providing the social solution to the challenges of BIM-Level 2 adoption. The reactive opportunities for enhancing benefits include clarity in communication whilst proactive opportunities for enhancing other benefits include the need for standardised processes and procedures, improved collaboration, transparency amongst parties in BIM-enabled projects and the need for project parties to check works and not fully rely on the automated processes in determining accuracy.

This study guides infrastructure project actors in effectively managing change on time, within budget and overcoming challenges experienced in non-BIM projects. The results from this study are timely for the Digital Build Britain agenda in maximising social factors in the socio-technical BIM process. Though the study was carried out in the UK, findings may be generalised given that the core BIM-Level 2 process is the same irrespective of the country, but these are not applicable to BIM-Levels 0 and 1 where no collaboration exist. Future work on further exploring emerging benefits and identifying the antecedents for the identified reactive opportunities and proactive opportunities, is recommended.

However, this study has some limitations. First, the sample used for the questionnaire and the subsequent interviews can be larger in subsequent studies to capture a broader spectrum of viewpoints. This notwithstanding, given the relatively short period of BIM Level 2 implementation, the sample used for the study is sufficient. Lastly, the results in this study represents a snapshot in time of practitioner viewpoints. With BIM Level 2 being implemented on more projects, it will be important to conduct this study again to investigate how these perceptions of benefits and challenges have changed over time.

\section{References}

Abd Jamil, A. H., \& Fathi, M. S. (2018). Contractual challenges for BIM-based construction projects: a systematic review. Built Environment Project and Asset Management, 8(4), 372-385.

Akbar, F. (2013). What affects students' acceptance and use of technology? Dietrich College Honors Theses. Carnegie Mellon University.

Al Hattab, M., \& Hamzeh, F. (2015). Using social network theory and simulation to compare traditional versus BIM-lean practice for design error management. Automation in Construction, 52, 59-69.

Alreshidi, E., Mourshed, M., \& Rezgui, Y. (2017). Factors for effective BIM governance. Journal of Building Engineering, 10, 89-101. 
Arayici, Y., Coates, P., Koskela, L., Kagioglou, M., Usher, C., \& O'reilly, K. (2011). Technology adoption in the BIM implementation for lean architectural practice. Automation in construction, 20(2), 189-195.

Anderson, A., Marsters, A., Dossick, C. S., \& Neff, G. (2012). Construction to operations exchange: Challenges of implementing COBie and BIM in a large owner organization. In Construction Research Congress 2012: Construction Challenges in a Flat World (pp. 688-697).

Azhar, S. (2011). Building information modeling (BIM): Trends, benefits, risks, and challenges for the AEC industry. Leadership and management in engineering, 11(3), 241-252.

Azhar, S., Khalfan, M., \& Maqsood, T. (2015). Building information modelling (BIM): now and beyond. Construction Economics and Building, 12(4), 15-28.

Barlish, K. and Sullivan, K. (2012). How to measure the benefits of BIM-A case study approach. Automation in construction, 24, pp.149-159.

Bataw, A., Burrows, M., \& Kirkham, R. (2014). The challenges of adopting building information modelling (BIM) principles within Small to Medium sized Enterprises (SMEs). In Proceedings of the 14th International Conference on Construction Applications of Virtual Reality (CONVR2014), 16-18 November 2014, Sharjah, UAE. (pp. 318-324). CONVR.

BIMplus. (2018). Projects. CIOB. Available at: http://www.bimplus.co.uk/projects/client-dips-its-toe-bimfirst-time/

Bryde, D., Broquetas, M., \& Volm, J. M. (2013). The project benefits of building information modelling (BIM). International journal of project management, 31(7), 971-980.

Building smart (2016). Developing the standards, tools and training that will drive the uptake of open BIM.

Caballero A. (2017) Case Study: 39 Victoria Street, London Willmott Dixon's Inside Job For DOH

Chen, C.-S., Tsui, Y.-K., Dzeng, R.-J. \& Wang, W.-C. (2015) Application of project-based change management in construction: a case study [online]. Journal of Civil Engineering and Management. 21 (1), pp. 107-118.

Chen, L. \& Luo, H. (2014) A BIM-based construction quality management model and its applications [online]. Automation in Construction. 46pp. 64-73.

Coates P., Arayici Y., Koskela K., Kagioglou M., Usher C., O'Reilly K., (2010) The key performance indicators of the BIM implementation process, ICCBE, Nottingham, UK

Construction Industry Institute (1994). Project Change Management. Austin Texas

Davies, A., and Brady, T. (2016). Explicating the dynamics of project capabilities. International Journal of Project Management, 34(2), pp.314-327. 
Doumbouya, L., Gao, G., \& Guan, C. (2016). Adoption of the Building Information Modeling (BIM) for construction project effectiveness: Review of BIM benefits. American Journal of Civil Engineering and Architecture, 4(3), 74-79.

Eadie, R., Browne, M., Odeyinka, H., McKeown, C., \& McNiff, S. (2015). A survey of current status of and perceived changes required for BIM adoption in the UK. Built Environment Project and Asset Management, 5(1), 4-21.

Elmualim, A., \& Gilder, J. (2014). BIM: innovation in design management, influence and challenges of implementation. Architectural Engineering and design management, 10(3-4), 183-199.

Engwall, M. (2002). "The futile dream of the perfect goal", in Sahlin-Andersson, K. and Soderholm, A. (Eds), Beyond Project Management, Liber, Malmo".

Erdogan, B., Anumba, C., Bouchlaghem, D., \& Nielsen, Y. (2005). Change management in construction: the current context. In 21st Annual ARCOM Conference, pp. 1085-1095, SOAS, University of London, Association of Researchers in Construction Management.

Farnsworth, C. B., Beveridge, S., Miller, K. R., \& Christofferson, J. P. (2015). Application, advantages, and methods associated with using BIM in commercial construction. International Journal of Construction Education and Research, 11(3), 218-236.

Fellows, R. \& Liu, A. (2008). Research Methods for Construction 3rd ed., Chichester: Blackwell publishing.

Ghaffarianhoseini, A., Tookey, J., Ghaffarianhoseini, A., Naismith, N., Azhar, S., Efimova, O., \& Raahemifar, K. (2017). Building Information Modelling (BIM) uptake: Clear benefits, understanding its implementation, risks and challenges. Renewable and Sustainable Energy Reviews, 75, 1046-1053.

Glaser, B.G. (2002), September. Constructivist grounded theory? In Forum qualitative sozialforschung/forum: Qualitative social research (Vol. 3, No. 3).

Gledson, B., Greenwood, D., Routledge, P., Watson, R., \& Woddy, P. (2016). Preparing to work in level 2 BIM: an innovative approach to a training and educational need. In: 1st International UK BIM Academic Forum Conference, September 13th-15th, 2016, Glasgow Caledonian University.

Green, S.D., Kao, C. \& Larsen, G.D. (2010). Contextualist research: Iterating between methods while following an empirically grounded approach. Journal of Construction Engineering and Management, 136(1), pp.117-126.

Hannah, D. R., \& Lautsch, B. A. (2011). Counting in qualitative research: Why to conduct it, when to avoid it, and when to closet it. Journal of Management Inquiry, 20(1), 14-22.

Hao, Q., Shen, W., Neelamkavil, J. \& Thomas, R. (2008a). Change Management in Construction Projects. CIB W78 International Conference on Information Technology in Construction. pp. 1-11.

Hardin, B. and McCool, D. (2015). BIM and construction management: proven tools, methods, and workflows. John Wiley \& Sons. 
Hayes, J. (2014). The theory and practice of change management. Palgrave Macmillan.

Helfat, C. E., \& Winter, S. G. (2011). Untangling dynamic and operational capabilities: Strategy for the (N) ever-changing world. Strategic Management Journal, 32(11), 1243-1250.

Hughes, D., Williams, T., \& Ren, Z. (2012). Is incentivisation significant in ensuring successful partnered projects? Engineering, Construction and Architectural Management, 19(3), 306-319.

Karimidorabati, S., Haas, C.T. \& Gray, J. (2016). Evaluation of automation levels for construction change management [online]. Engineering, Construction and Architectural Management. 23 (5), pp. 554-570.

Khosrowshahi, F., \& Arayici, Y. (2012). Roadmap for implementation of BIM in the UK construction industry. Engineering, Construction and Architectural Management, 19(6), 610-635.

Landis, J.R., and Koch, G.G. (1977). The measurement of observer agreement for categorical data. Biometrics 33, 159-74.

Lee, S., \& Peña-Mora, F. (2007). Understanding and managing iterative error and change cycles in construction. Built Environment. 8 (4), pp. 267-271.

Lin, Y. C., \& Yang, H. H. (2018). A Framework for Collaboration Management of BIM Model Creation in Architectural Projects. Journal of Asian Architecture and Building Engineering, 17(1), 39-46.

Liu, F., Jallow, A.K., Anumba, C.J. \& Wu, D. (2014). A Framework for Integrating Change Management with Building Information Modeling. Journal of Chemical Information and Modeling. 53 (9), pp. 16891699.

Liyanage, C. (2016). Construction in a changing world. Built Environment Project and Asset Management, 6(2).

Milliken, F. J., Morrison, E. W., \& Hewlin, P. F. (2003). An exploratory study of employee silence: Issues that employees don't communicate upward and why. Journal of management studies, 40(6), 14531476.

Motawa, I.A., Anumba, C.J., Lee, S. \& Pena-Mora, F. (2007). An integrated system for change management in construction. Automation in Construction. 16 (3), pp. 368-377.

NBS., (2017). National BIM Report 2016 [online]. Available from: https://www.thenbs.com/knowledge/national-bim-report-2016

Newton, K., \& Chileshe, N. (2012). Awareness, usage and benefits of building information modelling (BIM) adoption-The case of the South Australian construction organisations. In Proceedings of the 28th Annual ARCOM Conference, pp. 3-12, Edinburgh, UK, Association of Researchers in Construction Management.

Peterson, F., Hartmann, T., Fruchter, R. \& Fischer, M. (2011). Teaching construction project management with BIM support: Experience and lessons learned [online]. Automation in Construction. 20 (2), pp. 115-125. 
ProjectSmart (2013). Change-management. [online]. Available from:

http://www.projectsmart.co.uk/change-management.html.

PwC. (2018). BIM Level 2 Benefits measurement methodology. Available at:

https://www.cdbb.cam.ac.uk/Downloads/Level2/3.PwCBenefitsMeasurementMethodology.pdf

Sanchez, A. X., Hampson, K. D., \& Vaux, S. (Eds.). (2016). Delivering Value with BIM: A whole-of-life approach. Routledge, London.

Skanska. (2018). The Royal hospital. Available at:

https://group.skanska.com/48e49b/globalassets/about-us/building-information-modeling/bim-

projects/bim-barts-and-the-royal-london-hospital.pdf

Stepp, R. E., \& Michalski, R. S. (1986). Conceptual clustering of structured objects: A goal-oriented approach. Artificial Intelligence, 28(1), 43-69.

Talebi, S. (2014). Exploring advantages and challenges of adaptation and implementation of BIM in project life cycle. In 2nd BIM International Conference on Challenges to Overcome. BIMForum Portugal.

Tulenheimo, R. (2015). Challenges of implementing new technologies in the world of BIM-Case study from construction engineering industry in Finland. Procedia Economics and Finance, 21, 469-477.

Tulubas Gokuc, Y., \& Arditi, D. (2017). Adoption of BIM in architectural design firms. Architectural Science Review, 60(6), 483-492.

Whyte, J., Stasis, A., \& Lindkvist, C. (2016). Managing change in the delivery of complex projects: Configuration management, asset information and 'big data'. International Journal of Project Management, 34(2), 339-351.

Zeb, J., Froese, T., \& Vanier, D. (2015). An ontology-supported asset information integrator system in infrastructure management. Built Environment Project and Asset Management, 5(4), 380-397. 